\title{
Mechanisms linking brain insulin resistance to Alzheimer's disease
}

\author{
Maria Niures P.S. Matioli ${ }^{1}$, Ricardo Nitrini²
}

\begin{abstract}
Several studies have indicated that Diabetes Mellitus (DM) can increase the risk of developing Alzheimer's disease (AD). This review briefly describes current concepts in mechanisms linking DM and insulin resistance/deficiency to AD. Insulin/insulin-like growth factor (IGF) resistance can contribute to neurodegeneration by several mechanisms which involve: energy and metabolism deficits, impairment of Glucose transporter-4 function, oxidative and endoplasmic reticulum stress, mitochondrial dysfunction, accumulation of AGES, ROS and RNS with increased production of neuro-inflammation and activation of pro-apoptosis cascade. Impairment in insulin receptor function and increased expression and activation of insulin-degrading enzyme (IDE) have also been described. These processes compromise neuronal and glial function, with a reduction in neurotransmitter homeostasis. Insulin/GF resistance causes the accumulation of ABPP-A $\beta$ oligomeric fibrils or insoluble larger aggregated fibrils in the form of plaques that are neurotoxic. Additionally, there is production and accumulation of hyper-phosphorylated insoluble fibrillar tau which can exacerbate cytoskeletal collapse and synaptic disconnection.
\end{abstract}

Key words: Alzheimer's disease, diabetes mellitus, insulin resistance, neurodegeneration, mechanisms.

\section{MECANISMOS QUE LIGAM A RESISTÊNCIA INSULÍIICA CEREBRAL À DOENÇA DE ALZHEIMER: UMA BREVE REVISÃo}

RESUMO. Atualmente, muitos estudos têm indicado que o Diabetes Mellitus (DM) pode aumentar o risco de desenvolver doença de Alzheimer (DA). Esta revisão tem o objetivo de descrever brevemente os conceitos atuais sobre os mecanismos que associam DM, resistência/deficiência de insulina à DA. Resistência à insulina/fator de crescimento similar à insulina (IGF) pode contribuir para a neurodegeneração através de vários mecanismos os quais envolvem: déficit metabólico e energético, prejuízo na função do transportador de glicose-4, estresse oxidativo e do retículo endoplasmático, disfunção mitocondrial, acúmulo de AGEs, ROS e RNS com aumento na produção da neuro-inflamação e ativação da cascata pró-apoptóptica. Prejuízo na função do receptor de insulina, aumento na expressão e ativação da enzima de degradação da insulina (EDI) também têm sido descritos. Esses processos comprometem a função neuronal e glial, com redução da homeostase de neurotransmissor. Resistência à insulina/IGF causa acúmulo de fibrilas de oligômeros de PPßA- $\beta A$ e grandes agregados fibrilares insolúveis em forma de placas que são neurotóxicos. Adicionalmente, há produção e acúmulo de fibrilas insolúveis de tau hiperfosforilada que podem exacerbar o colapso do citoesqueleto e a desconexão sináptica.

Palavras-chave: doença de Alzheimer, diabetes mellitus, resistência insulínica, neurodegeneração, mecanismos.

\section{INTRODUCTION}

Dopulation aging is a global phenomenon leading to an increase in chronic diseases such as dementia and diabetes mellitus (DM), which pose an epidemic challenge to global health care systems. In 2012, the WHO published that 35.6 million people had dementia worldwide and that this number is set to reach
65.7 million by $2030 .{ }^{1}$ Alzheimer's disease $\mathrm{AD}$ ) is the most common cause of dementia, especially in the elderly population. ${ }^{1}$ Recently, the International Diabetes Federation ${ }^{2}$ estimated that 382 million people had diabetes in 2013, where this number may rise to 592 million within less than 25 years. ${ }^{2}$ Moreover,

\footnotetext{
1Pós-graduanda, nível de Doutorado, Departamento de Neurologia da Faculdade de Medicina da Universidade de São Paulo. ${ }^{2}$ Professor Titular da Disciplina de Neurologia da Faculdade de Medicina da Universidade de São Paulo. Orientador e Professor Responsável pela Pós-graduação do Departamento de Neurologia da
} Faculdade de Medicina da Universidade de São Paulo.

Maria Niures P. S.Matioli. Av. Almirante Cochrane, 123 / 101-11040-001 Santos SP - Brasil. E-mail: matioli@kingnet.com.br; niures.matioli@usp.br.

Disclosure: The authors report no conflicts of interest.

Received September 11, 2014. Accepted in final form December 20, 2014. 
$80 \%$ of the total number affected live in low- and middle-income countries and Type 2 diabetes (T2DM) is the most common type of DM. ${ }^{2}$ The prevalence of $\mathrm{AD}$ and T2DM increases with aging. ${ }^{3}$

The $\mathrm{AD}$ pathology is characterized by the accumulation of the following in the brain: amyloid beta precursor protein $(\mathrm{A} \beta \mathrm{PP})-\mathrm{A} \beta$ large insoluble fibrillar aggregates in the form of plaques, soluble neurotoxic oligomeric fibrils, hyper-phosphorylation of tau protein with neurofibrillary tangles (NFTs) deposition, dystrophic neuritis, and neuropil threads. ${ }^{4,5}$ In familial forms of $\mathrm{AD}$, the mutations in A PPP, presenilin 1 (PS1) and 2 (PS2) genes, or inheritance of the Apolipoprotein E e4 (ApoE-e4) allele can cause increased synthesis and deposition of A $\beta P P-$ $\mathrm{A} \beta{ }^{6,7}$ However, the cause of A $\beta \mathrm{PP}-\mathrm{A} \beta$ accumulation in sporadic $\mathrm{AD}$, the most common form of the disease, remains unknown. ${ }^{5}$ However, evidence suggests that impairment in insulin and insulin-like growth factor (IGF) compromises $\mathrm{A} \beta \mathrm{PP}$ expression and protein processing which could be responsible for $\mathrm{A} \beta \mathrm{PP}-\mathrm{A} \beta$ accumulation. ${ }^{8}$

The association between $\mathrm{DM}$ and $\mathrm{AD}$ is controversial in literature. ${ }^{9,10}$ Many studies have demonstrated a positive association between $\mathrm{DM}$ and $\mathrm{AD}$, especially in epidemiological research, studies in animals and cells, ${ }^{11-17}$ but these findings have not been entirely confirmed in neuropathological studies. ${ }^{3,18-23}$ Based on this positive association, researchers have studied DM treatments as a target to diminish or avoid $\mathrm{AD}$ onset and progression. ${ }^{24-28}$

The exact mechanisms by which DM affects the brain remain unclear, but this probably occurs through cerebrovascular and neurodegenerative changes. ${ }^{29}$ The aim of this article was to provide a brief review on the main mechanisms associating $\mathrm{AD}$ with $\mathrm{DM}$ due to insulin resistance and deficiency.

Insulin and insulin-like growth factor actions in the central nervous system. The insulin produced by the pancreas can cross the blood brain barrier (BBB) from the circulation to the brain by a receptor-dependent mechanism, ${ }^{30}$ but the levels of insulin expression in the brain are modest compared to circulating levels. ${ }^{10}$ The transport of peripheral insulin across the $\mathrm{BBB}$ and the consequences of peripheral hyperinsulinemia or hypoinsulinemia are significantly important to cerebral insulin signaling. ${ }^{10}$ Insulin binding activity has been identified in the brain in a number of species, including humans. ${ }^{31,32}$ Furthermore, insulin receptors (IR) are expressed in cerebral vasculature and can mediate insulin traffic across the $\mathrm{BBB}^{33}$

Insulin and IGF play an important role in brain function and structure. ${ }^{5}$ Insulin, IGF-1 and IGF-2 poly- peptides and receptor genes are expressed in neurons $s^{34}$ and glia, ${ }^{35,36}$ particularly in structures that are targeted in neurodegenerative diseases. ${ }^{34,35,37}$ IGF and insulin are associated with regulating and maintaining cognitive function, ${ }^{38}$ and participate in neuronal and glial functions such as growth, metabolism, survival, gene expression, protein synthesis, cytoskeletal assembly, neurotransmitter function, synapse formation and plasticity. ${ }^{34,39}$

Glucose transporter 4 (GLUT4) is very important for glucose uptake and utilization in the brain. ${ }^{38}$ Insulin stimulates GLUT4 gene expression and protein trafficking from the cytosol to the plasma membrane, modulating glucose uptake and utilization. ${ }^{38}$ Consequently, the regulation of neuronal metabolism and the generation of energy needed for cognition and memory are linked to insulin stimulation of GLUT4. ${ }^{38}$ GLUT4 is abundantly expressed along with insulin receptors, in medial temporal lobe structures which are affected in $\mathrm{AD}$ pathology. Nevertheless, post-mortem brain studies have not detected significant reductions in GLUT4 expression in $\mathrm{AD} .{ }^{40}$ Deficits in brain glucose utilization and energy metabolism, and brain insulin/IGF resistance could be mediated by impairments in GLUT4 trafficking between the cytosol and plasma membrane. ${ }^{38}$

Insulin and IGF binding to their own receptors activates some pathways, leading to phosphorylation and activation of intrinsic receptor tyrosine kinases. The phosphorylated receptors interact with IR substrate molecules and promote transmission of downstream signals that stimulate growth, survival, metabolism, plasticity and inhibit apoptosis. ${ }^{38}$

Brain insulin/IGF resistance and AD. AD has been associated with deficits in insulin/IGF signaling due to the effects of insulin/IGF resistance and deficiency. ${ }^{5}$ Deficits in cerebral glucose utilization have been described in the early stages of AD. ${ }^{41-44}$ Suzanne de la Monte and colleagues have proposed the concept of $\mathrm{AD}$ as "Type 3 diabetes". ${ }^{40}$ They observed an inverse correlation between IR abundance and the Braak score of $\mathrm{AD}$ brains, with $80 \%$ reduced IR substrates levels in the most severe cases. They described reduced messenger RNA levels of IGF-1 and increased Tau protein levels regulated by IR. ${ }^{40,45}$ Studies with small interfering RNA molecules showed that molecular disruption of brain insulin and IGF receptors was sufficient to cause cognitive impairment and hippocampal degeneration similar to $\mathrm{AD}$ molecular abnormalities. ${ }^{46}$

Brain insulin/IGF resistance/deficiency can appear independently of Type 1 and Type 2 diabetes. ${ }^{5}$ Neuro- 
degeneration can occur by several mechanisms such as the activation of kinases that aberrantly phosphorylate tau, the expression of $\mathrm{A} \beta \mathrm{PP}$ and accumulation of $\mathrm{A} \beta \mathrm{PP}-\mathrm{A} \beta$ in brain insulin/IGF resistance. ${ }^{38}$ Hyperglycemia leads to the accumulation of advanced glycation end products (AGEs) that disrupts removal of $A \beta 42$ and induces $A \beta$ and Tau glycation, promoting $A \beta$ aggregation and NFTs formation in the brain. ${ }^{38,47,48}$ AGE production is found in normal aging, but becomes highly accelerated in diabetes. ${ }^{49}$ Recent evidence suggests that glyceraldehyde-derived AGEs (glycer-AGE) are the predominant modification of the most toxic forms of AGEs, and Glycer-AGE-modified proteins are directly toxic to cultured neurons. Diabetic serum enriched with glycer-AGE modified proteins has shown toxic effects on neurons..$^{10}$ AGEs are also linked to microvascular alterations in hyperglycemia and diabetes..$^{50}$ Receptor for advanced glycation end products (RAGE) expression has been associated with pathological conditions such as diabetic vascular disease, chronic inflammation and AD. ${ }^{51,52}$ Studies with immunohistochemistry for RAGE in $\mathrm{AD}$ brains have demonstrated that RAGE increased expression in neurons, microglia, astrocytes and vascular endothelial cells. ${ }^{53,54}$ RAGE binds and interacts with AGEs and also with $A \beta .^{49}$ RAGE interaction with AGEmodified proteins in either diabetes or $A D$, or $A \beta$ in $\mathrm{AD}$, can produce damaging inflammatory responses ${ }^{55,56}$ and be responsible for vascular complications in DM and $A D{ }^{57-59}$ RAGE mediates the transport of plasma $A \beta$ across the $\mathrm{BBB}^{60}$ and the migration of monocytes across the human brain endothelial cells in response to $A \beta .{ }^{61}$

Microvascular disease is seen as a consequence of diabetes and can also be found in AD brains, possibly contributing to the cognitive impairment and neurodegeneration seen in AD. ${ }^{5,62}$ Decreased blood flow and impairment of oxygen and nutrient delivery exacerbate the adverse effects of insulin/IGF resistance. ${ }^{63}$ Consequently, there is an increase in oxidative stress and activation of signaling mechanisms which promote aberrant tau phosphorylation, $\mathrm{A} \beta \mathrm{PP}$ cleavage, $\mathrm{A} \beta \mathrm{PP}-\mathrm{A} \beta$ deposition, and mitochondrial dysfunction. ${ }^{38,63}$

IR function is compromised in brain insulin/IGF resistance, leading to many adverse effects. There is decreased signaling through IR substrate, phosphoinositol-3-kinase (PI3K) and Akt, with reduced neuronal and oligodendroglial survival, neuronal plasticity and myelin maintenance. ${ }^{38}$ IR dysfunction increases activation of glycogen synthetase kinase $3 \beta$ (GSK-3 $\beta$ ) and phosphatases that negatively regulate insulin signaling, consequently producing increased tau phosphorylation, oxidative stress, neuro-inflammation and pro-apoptosis signaling. ${ }^{38}$ Reduced insulin-responsive gene expression seen in IR dysfunction can lead to deficits in acetylcholine and glucose metabolism. ${ }^{38}$

Impairment in GLUT4 functions in brain with insulin/IGF resistance results in reduced glucose uptake and utilization, consequently compromising cell energy and homeostatic functions, disrupting neuronal cytoskeleton and synaptic connection. ${ }^{38}$ Deficits in energy metabolism lead to increased oxidative and endoplasmic reticulum (ER) stress, and mitochondrial dysfunction with the generation of reactive oxygen (ROS) and reactive nitrogen species (RNS). ${ }^{64-66}$ Increased oxidative stress, ROS and RNS damage RNA, DNA, proteins, and lipid peroxidation production, energy deficits, cell death, increased $A \beta P P$ expression, $A \beta 42$ deposition and fibrillarization. ${ }^{38}$ There is activation of pro-inflammatory and pro-death cascades and down-regulation of target genes that mediate cholinergic homeostasis linked to $\mathrm{AD}$ in brain with insulin/IGF resistance. ${ }^{5,67}$ Impairment of myelin maintenance also occurs and can lead to increased neuro-inflammation, oxidative stress, proapoptosis, and further insulin resistance, besides white matter atrophy. ${ }^{38}$

The insulin-degrading enzyme (IDE) has the property of catabolizing insulin and $A \beta$, and may play a critical role in $A \beta$ clearance in the brain as $A \beta$ scavenger protease. $^{68,69}$ IDE acts as a general regulator of amyloid burden in the pancreas and brain. ${ }^{70}$ Insulin regulates IDE expression and can directly compete with $\mathrm{A} \beta$ for binding to IDE. ${ }^{71}$ In hyper-insulin states, IDE can be diverted to degrade insulin, consequently allowing $\mathrm{A} \beta \mathrm{PP}-\mathrm{A} \beta$ accumulation. ${ }^{70}$ Mutations in the IDE gene in mice resulted in reduced activity of this enzyme, lower rates of $A \beta$ and insulin degradation, additionally developing hyperinsulinaemia and accumulating $A \beta$ species in their brains. ${ }^{72}$ Chronic hyperglycaemia, hyperinsulinaemia, oxidative stress, accumulation of AGEs, increased expression and activation of IDE, increased production of pro-inflammatory cytokines, and cerebral microvascular disease associated with peripheral insulin resistance could result in mild cognitive impairment and neurodegeneration. ${ }^{38,73}$

Brain insulin/IGF resistance and A $\beta$ pathology. Altered proteolysis with increased $\mathrm{A} \beta \mathrm{PP}$ gene expression results in the accumulation of 40 or 42 amino acid length $A \beta$ peptides that can aggregate and have been described in $\mathrm{AD}$ pathology. Dysregulated expression and processing of $\mathrm{A} \beta \mathrm{PP}$ leads to the accumulation of $\mathrm{A} \beta \mathrm{PP}-\mathrm{A} \beta$ oligomeric fibrils or insoluble larger aggregated fibrils in the form of plaques that are neurotoxic..$^{5}$ The interest in the role of impaired insulin/IGF signaling as either the cause or 
consequence of dysregulated $\mathrm{A} \beta \mathrm{PP}-\mathrm{A} \beta$ expression and protein processing has grown in literature..$^{38}$ Insulin can accelerate trafficking of $\mathrm{A} \beta \mathrm{PP}-\mathrm{A} \beta$ from the trans-Golgi network to the plasma membrane as well as its extracellular secretion ${ }^{74}$ and also inhibits its intracellular degradation by IDE. ${ }^{75}$ Impaired insulin signaling can disrupt both the processing of $\mathrm{A} \beta \mathrm{PP}$ and clearance of $\mathrm{A} \beta \mathrm{PP}-\mathrm{A} \beta{ }^{76}{ }^{76}$ Simultaneously, $\mathrm{A} \beta \mathrm{PP}-\mathrm{A} \beta$ affects insulin signaling by competing with insulin, or reducing the affinity of insulin for binding to its own receptor. ${ }^{77} \mathrm{~A} \beta \mathrm{PP}-\mathrm{A} \beta$ oligomers desensitize and reduce the surface expression of IRs, consequently inhibiting neuronal insulin-signaling. ${ }^{67}$ Additionally, intracellular A $\beta P P-A \beta$ interferes with PI3k activation of Akt, leading to reduced signaling, increased activation of GSK-3 $\beta$, and hyper-phosphorylation of tau. Increased levels of GSK-3 promote A $\beta P P$ processing and $\mathrm{A} \beta \mathrm{PP}-\mathrm{A} \beta$ accumulation. ${ }^{78}$

Brain insulin/IGF resistance and Tau pathology. In $A D$, the main neuronal cytoskeletal lesions correlated with severity of dementia, including NFTs and dystrophic neurites, contain aggregated and ubiquitinated insoluble fibrillar tau. ${ }^{4,38,79}$ Tau gene expression and phosphorylation can be regulated by insulin/IGF stimulation. ${ }^{80,81}$ Reduced insulin/IGF signaling can impair tau gene expression and contribute to tau pathology. ${ }^{82}$ Brain insulin/IGF resistance results in decreased signaling through PI3K, Akt, ${ }^{80,81}$ and $\mathrm{Wnt} / \beta$-catenin, ${ }^{83}$ and increased activation of GSK-3 $\beta .^{84,85}$ The hyper-phosphorylation of tau, which leads to tau misfolding and fibril aggregation in $\mathrm{AD}$ pathology, can be partly due to GSK-3 $\beta$ overactivation. ${ }^{86}$ Tau hyper-phosphorylation is mediated by increased activation of cyclin-dependent kinase 5 (cdk-5) and cAbl kinases, ${ }^{87,88}$ and inhibition of protein phosphatases 1 and 2 A. ${ }^{88,89}$ Tau protein misfolds and self-aggregates into insoluble fibrillar structures lead to neurofibrillary tangles, dystrophic neurites, and neuropil threads. ${ }^{38,90}$ The results of generation and accumulation of hyperphosphorylated insoluble fibrillar tau are the exacerbation of cytoskeletal collapse, neurite retraction, and synaptic disconnection..$^{38}$ Table 1 summarizes the main mechanisms linking brain insulin/IGF resistance to $\mathrm{AD}$ pathology.

\section{Neurodegenerative process contributing to brain insulin resis-} tance in AD. Interestingly, the neuropathological process involved in $\mathrm{AD}$ can reinforce brain insulin resistance. $\mathrm{A} \beta$ toxicity, microvascular disease, oxidative stress, transition metal ion accumulations and hyperphosphorylated-ubiquitinated tau lead to increased brain insulin resistance. ${ }^{38} \mathrm{~A} \beta 42$ toxicity competes with insulin and reduces the affinity of insulin binding to its receptor. ${ }^{77,91}$ $\mathrm{A} \beta \mathrm{PP}$ oligomers desensitize and reduce surface expression of insulin receptors, and interfere with PI3K activation of Akt. ${ }^{38,92}$ The $A \beta$ toxicity disrupts insulin signaling and impairs insulin stimulated neuronal survival

Table 1. Summary of mechanisms linking brain insulin/GF resistance to AD pathology.

\begin{tabular}{ll}
\hline Mechanisms & Consequences \\
\hline $\begin{array}{l}\text { Impairment of GLUT4 } \\
\text { function }\end{array}$ & - Energy deficits: memory and cognition impairment; disruption of neuronal cytoskeleton and synaptic connection. \\
\hline Changes in insulin receptor & $\begin{array}{l}\text { - Increased activation of GSK-3and phosphatases: tau phosphorylation, oxidative stress, neuro-inflammation, pro- } \\
\text { functions }\end{array}$ \\
& apoptosis signaling. \\
& Decreased IR substrate, PI3K-Akt activity: reduced neuronal and oligodendroglial survival, neuronal plasticity, myelin \\
& maintenance. \\
& Reduced insulin-responsive gene expression: deficits in acetylcholine and glucose metabolism. \\
& Impairment in tau gene expression: hyper-phosphorylation of tau leading to tau misfolding and fibril aggregation, \\
& NFTs.
\end{tabular}

Energy deficit and

- Increased oxidative and endoplasmic reticulum stress, and mitochondrial dysfunction with ROS and RNS generation. hypometabolism

\begin{tabular}{|c|c|}
\hline $\begin{array}{l}\text { Increased oxidative stress, } \\
\text { ROS and RNS }\end{array}$ & $\begin{array}{l}\text { - Damaged RNA, DNA, proteins, and lipid peroxidation production, energy deficits, cell death, increased AßPP expres- } \\
\text { sion with A } \beta 42 \text { deposition and fibrillarization. }\end{array}$ \\
\hline
\end{tabular}

hyperglycemia

- Enhances AGE production and impairs RAGE expression: microvascular disease with brain hypoperfusion, inflammatory responses, impairment in removal of $A \beta 42$ leading to $A \beta 42$ deposition.

AD:Alzheimer disease; GLUT4 Glucose transporter 4; IR: insulin receptor; PI3K: phosphoinositol-3-kinase; NFTs: neurofibrillary tangles; ROS: reactive oxygen species; RNS: reactive nitrogen species; A $\beta$ PP: amyloid beta precursor protein; A $\beta 42$ : amyloid beta 42; AGE: advanced glycation end products; RAGE: receptor for advanced glycation end products. 
and plasticity. ${ }^{38}$ Oxidative stress can produce increases in neuro-inflammation and pro-inflammatory cytokine inhibition of insulin signaling. ${ }^{38}$ Transition metal ion accumulations produce mitochondrial dysfunction, oxidative stress, tau and A $\mathrm{PP}$ oligomer fibrillarization, which impair glucose uptake and utilization, and inhibit insulin signaling. ${ }^{38}$ Hyperphosphorylated-ubiquitinated tau increases oxidative stress, promotes neuroinflammation which consequently enhances insulin resistance. ${ }^{38}$ Microvascular disease exacerbates insulin resistance through cerebral hypoperfusion and hypoxic-ischemic injury. ${ }^{38}$

Conclusions. A body of evidence has shown that the structural and functional integrity of the CNS can be compromised in the presence of brain insulin and IGF resistance or deficiency. These changes can contribute to $\mathrm{AD}$ pathology and conversely, $\mathrm{AD}$ pathology can enhance brain insulin and IGF resistance, functioning as a positive feedback loop. However, it is necessary to bear in mind that the majority of studies have been conducted in the experimental field with animal or cell models. Elucidating the question of a connection among $\mathrm{DM}$, brain insulin resistance/deficiency and $\mathrm{AD}$ is very important, especially for planning novel strategies to prevent and treat $\mathrm{AD}$ in the future.

Author contribution. Maria Niures P.S. Matioli drafted the manuscript, and Ricardo Nitrini critically revised the manuscript.

\section{REFERENCES}

1. World Health Organization. Dementia: a public health priority. WHO Library 2012.

2. International Diabetes Federation, sixth edition. Diabetes Atlas, 2014. www.idf.org/diabetesatlas.

3. Janson J, Laedtke T, Parisi JE, O'Brien P, Petersen RC, Butler PC. Increased risk of type 2 diabetes in Alzheimer disease. Diabetes 2004; 53:474-481.

4. Duyckaerts C, Delatour B, Potier MC. Classification and basic pathology of Alzheimer disease. Acta Neuropathol 2009;118:5-36.

5. de la Monte S M and Tong M. Brain metabolic dysfunction at the core of Alzheimer's disease. Biochem Pharmacol 2014;88:548-559.

6. Robakis NK. Mechanisms of AD neurodegeneration may be independent of Abeta and its derivatives. Neurobiol Aging 2011;32:372-9.

7. Wu L, Rosa-Neto P, Hsiung GY, et al. Early-onset familial Alzheimer's disease (EOFAD). Can J Neurol Sci 2012;39:436-445.

8. Bosco D, Fava A, Plastino M, Montalcini T, Pujia A. Possible implications of insulin resistance and glucose metabolism in Alzheimer's disease pathogenesis. J Cell Mol Med 2011;15:1807-1821.

9. Biessels GJ, Staekenborg S, Brayne C and Scheltens P. Risk of dementia in diabetes mellitus: a systematic review. Lancet Neurol 2006; 5:64-74.

10. Arab L, Sadeghi R, Walker DG, Lue LF and Sabbagh MN. Consequences of Aberrant Insulin Regulation in the Brain: Can Treating Diabetes be Effective for Alzheimer's Disease. Curr Neuropharmacol 2011;9:693-705.

11. Leibson CL, Rocca WA, Hanson VA, et al. Risk of dementia among persons with diabetes mellitus: a population-based cohort study. Am J Epidemiol 1997;145:301-308

12. Brayne C, Gill C, Huppert FA, et al. Vascular risks and incident dementia: results from a cohort study of the very old. Dement Geriatr Cogn Disord 1998;9:175-180.

13. Ott A, Stolk RP, van Harskamp F, et al. Diabetes mellitus and the risk of dementia: The Rotterdam Study. Neurology 1999;53:1937-1942.

14. Arvanitakis Z, Wilson RS, Bienias JL, et al. Diabetes mellitus and risk of Alzheimer disease and decline in cognitive function. Arch Neurol 2004;61:661-666.

15. LuchsingerJA, Reitz C, Honig LS, etal. Aggregation of vascular riskfactors and risk of incident Alzheimer disease. Neurology 2005;654:545-551.

16. Whitmer RA, Sidney S, Selby J, et al. Midlife cardiovascular risk factors and risk of dementia in late life. Neurology 2005;64:277-281.

17. Cheng D, Noble J, Tang MX, et al. Type 2 diabetes and late-onset Alzheimer's disease. Dement Geriatr Cogn Disord 2011;31:424-430.

18. Arvanitakis Z, Schneider JA, Wilson RS, at al. Diabetes is related to cerebral infarction but not AD pathology in older persons. Neurology 2006;67:1960-5.

19. Heitner J, Dickson D. Diabetes do not have increased Alzheimer' type pathology compared with age-matched controls subjects. A retro-

spective postmortem immunocytochemical and hisfluorescence study. Neurology 1997;49:1306-11.

20. Beeri MS, Silverman JM, Davis KL, et al. Type 2 Diabetes Is Negatively Associated with Alzheimer's disease Neuropathology. J Gerontol A Biol Sci Med Sci 2005;60:471-475.

21. Alafuzoff I, Aho L, Helisalmi S, Mannermaat A, Soininen H. $\beta$-Amyloid deposition in brains of subjects with diabetes. Neuropathol Appl Neurobiol 2009;35:60-68.

22. Nelson PT, Smith CD, Abner EA, et al. Human cerebral neuropathology of Type 2 diabetes mellitus. Biochimica et Biophysica Acta 2009; 1792:454-469.

23. Ahtiluoto S, Polvikoski T, Peltonen M, et al. Diabetes, Alzheimer disease, and vascular dementia: a population-based neuropathological study. Neurology, 2010;75:1195-1202.

24. Watson GS, Cholerton BA, Reger MA, et al. Preserved cognition in patients with early Alzheimer disease and amnestic mild cognitive impairment during treatment with rosiglitazone: a preliminary study. Am J Geriatr Psychiatry 2005;13:950-958.

25. Risner ME, Saunders AM, Altman JF, et al. Efficacy of rosiglitazone in a genetically defined population with mild-to-moderate Alzheimer's disease. Pharmacogenomics J 2006;6:246-254.

26. Roses AD. Commentary on "a roadmap for the prevention of dementia: the inaugural Leon Thal Symposium." An impending prevention clinical trial for Alzheimer's disease: roadmaps and realities. Alzheimers Dement 2008;4:164-166.

27. Reger MA, Watson GS, Green PS, et al. Intranasal insulin improves cognition and modulates beta-amyloid in early AD. Neurology 2008;70:440-448

28. Sato $\mathrm{T}$, Hanyu $\mathrm{H}$, Hirao $\mathrm{K}$, et al. Efficacy of PPAR- $\gamma$ agonist pioglitazone in mild Alzheimer disease. Neurobiol Aging 2011;32:1626-1633.

29. Bornstein NM, Brainin M, Guekht A, et al. Diabetes and the brain: issues and unmet needs. Neurol Sci 2014;35:995-1001.

30. Yu Y, Kastin AJ, Pan W. Reciprocal interactions of insulin and insulin-like growth factor I in receptor-mediated transport across the blood-brain barrier. Endocrinology 2006;147:2611-2615.

31. Roth RA, Morgan DO, Beaudoin J, Sara V. Purification and characterization of the human brain insulin receptor. J Biol Chem 1986;261:37533757 .

32. Kotzke G, Schutt M, Missler U, et al. Binding of human, porcine and bovine insulin to insulin receptors from human brain, muscle and adipocytes and to expressed recombinant alternatively spliced insulin receptor isoforms. Diabetologia 1995;38:757-763.

33. Pardrige WM, Eisenberg $\mathrm{J}$ and Yang J. Human blood-brain barrier insulin growth factor type 1 receptor signaling in the cells of oligodendrocyte lineage is required for normal in vivo oligodendrocyte development and myelination. receptor. J Neurochem 1985;44:1771-1778.

34. dela Monte SM, Wands JR. Review of insulin and insulin-like growth factor 
expression, signaling, and malfunction in the central nervous system: relevance to Alzheimer's disease. J Alzheimers Dis 2005;7:45-61.

35. Zeger M, Popken G, Zhang J, Xuan S, Lu QR, Schwab MH, et al. Insulin-like Glia 2007;55:400-11.

36. Freude S, Schilbach K, Schubert M. The role of IGF-1 receptor and insulin receptor signaling for the pathogenesis of Alzheimer's disease: from model organisms to human disease. Curr Alzheimer Res 2009; 6:213-223.

37. de la Monte SM, Longato L, Tong M, Wands JR. Insulin resistance and neurodegeneration: roles of obesity, type 2 diabetes mellitus and nonalcoholic steatohepatitis. Curr Opin Investig Drugs 2009;10:1049-1060.

38. de la Monte SM (b). Brain Insulin Resistence and Deficiency as Therapeutic Targets in Alzheimer's Disease. Curr Alzheimer Res 2012;9:35-66.

39. D'Ercole AJ, Ye P. Expanding the mind: insulin-like growth factor I and brain development. Endocrinology 2008;149:5958-5962.

40. Steen E, Terry BM, Rivera EJ, et al. Impaired insulin and insulin-like growth factor expression and signaling mechanisms in Alzheimer's disease--is this type 3 diabetes? J Alzheimers Dis 2005;7:63-80.

41. Caselli RJ, Chen K, Lee W, et al. Correlating cerebral hypometabolism with future memory decline in subsequent converters to amnestic premild cognitive impairment. Arch Neurol 2008;65:1231-1236.

42. Mosconi L, Pupi A, De Leon MJ. Brain glucose hypometabolism and oxidative stress in preclinical Alzheimer's disease. Ann N Y Acad Sci 2008;1147:180-95.

43. Mosconi L, Mistur R, Switalski R, et al. FDG-PET changes in brain glucose metabolism from normal cognition to pathologically verified Alzheimer's disease. Eur J Nucl Med Mol Imaging 2009;36:811-822.

44. Langbaum JB, Chen K, Caselli RJ, et al. Hypometabolism in Alzheimeraffected brain regions in cognitively healthy Latino individuals carrying the apolipoprotein E epsilon4 allele. Arch Neurol 2010;67:462-468.

45. Rivera EJ,GoldinA, Fulmer N, et al. Insulin and insulin-like growth factor expression and function deteriorate with progression of Alzheimer's disease: link to brain reductions in acetylcholine. J Alzheimers Dis 2005; 8:247-268.

46. de la Monte SM, Tong M, Bowling N, Moskal P. si-RNA inhibition of brain insulin or insulin-like growth factor receptors causes developmental cerebellar abnormalities: relevance to fetal alcohol spectrum disorder. Mol Brain 2011:4:13.

47. Goh SY, Cooper ME. Clinical review: role of advanced glycation end products in progression and complications of diabetes. J Clin Endocrinol Metab 2007;93:1143-1152.

48. Takuma K, Fung F, Zhanf W, et al. RAGE-mediated signaling contributes to intraneuronal transport of amyloid-beta and neuronal dysfunction. Proc Natl Acad Sci U S A 2009;106:20021-20026.

49. Ahmad W. Overlapped Metabolic and Therapeutic Links between Alzheimer and Diabetes. Mol Neurobiol 2013;47:399-424.

50. Srikanth V, Maczurek A, Phan T, et al. Advanced glycation endproducts and their receptor RAGE in Alzheimer's disease. Neurobiol Aging. 2011:32:763-777.

51. Naka Y, Bucciarelli LG, Wendt T, et al. RAGE axis: Animal models and novel insights into the vascular complications of diabetes. Arterioscler Thromb Vasc Biol 2004;24:1342-1349.

52. Bucciarelli $L G, W e n d t$, Rong $L$, et al. RAGE is a multiligand receptor of the immunoglobulin superfamily: implications for homeostasis and chronic disease. Cell Mol Life Sci 2002;59:1117-1128.

53. Jeynes B, Provias J. Evidence for altered LRP/RAGE expression in Alzheimer lesion pathogenesis. Curr Alzheimer Res 2008;5:432-437.

54. Miller MC, Tavares R, Johanson CE, et al. Hippocampal RAGE immunoreactivity in early and advanced Alzheimer's disease. Brain Res 2008; 1230:273-280

55. Lue LF, Yan SD, Stern DM,Walker DG. Preventing activation of receptor for advanced glycation endproducts in Alzheimer's disease. Curr. Drug Targets. CNS. Neurol Disord 2005;4:249-266.

56. Lue LF,Walker DG, Jacobson S, Sabbagh M. Receptor for advanced glycation end products: its role in Alzheimer's disease and other neurological diseases. Future Neurol 2009;4:167-177.

57. Hudson BI, Wendt T, Bucciarelli LG, et al. Diabetic vascular disease: it's all the RAGE. Antioxid. Redox Signal 2005;7:1588-1600.

58. Jandeleit-Dahm K, Watson A, Soro-Paavonen A. The AGE/RAGE axis in diabetes-accelerated atherosclerosis. Clin Exp Pharmacol Physiol 2008:35:329-334.

59. Yamagishi S, Nakamura K, Matsui T, et al. Agents that block advanced glycation end product (AGE)-RAGE (receptor for AGEs)-oxidative stress system: a novel therapeutic strategy for diabetic vascular complications. Expert Opin Investig Drugs 2008;17:983-996.

60. Deane R, Bell RD, Sagare A, Zlokovic BV. Clearance of amyloid-beta peptide across the blood-brain barrier: implication for therapies in Alzheimer's disease. CNS Neurol Disord Drug Targets. 2009;8:16-30.

61. Giri R, Selvaraj S, Miller CA, et al. Effect of endothelial cell polarity on beta-amyloid-induced migration of monocytes across normal and AD endothelium. Am J Physiol Cell Physiol 2002;283:C895-C904.

62. Korf ES, White LR, Scheltens P, Launer LJ. Brain aging in very old men with type 2 diabetes: the Honolulu-Asia aging study. Diabetes Care 2006;29:2268-2274

63. Chen GJ, Xu J, Lahousse AS, et al. Transient hypoxia causes Alzheimertype molecular and biochemical abnormalities in cortical neurons: potential strategies for neuroprotection. J Alzheimers Dis 2003;5:209-228.

64. Hoyer S, Lannert $\mathrm{H}$. Inhibition of the neuronal insulin receptor causes Alzheimer-like disturbances in oxidative/energy brain metabolism and in behavior in adult rats. Ann N Y Acad Sci 1999;893:301-303.

65. de la Monte SM, Wands JR. Chronic gestational exposure toethano impairs insulin-stimulated survival and mitochondrial function in cerebellar neurons. Cell Mol Life Sci 2002:59:882-893.

66. Hoyer S, Lee SK, Loffler T, Schliebs R. Inhibition of the neuronal insulin receptor. An in vivo model for sporadic Alzheimer disease? Ann N Y Acad Sci 2009;920:256-258.

67. de la Monte, Suzanne M. Contributions of Brain Insulin Resistance and Deficiency in Amyloid-Related Neurodegeneration in Alzheimer's Disease. Drugs 2012;72:49-66.

68. Qiu WQ, Walsh DM, Ye Z, Vekrellis K, et al. Insulindegrading enzyme regulates extracellular levels of amyloid beta-protein by degradation. $J$ Biol Chem 1998:273:32730-32738.

69. Ling Y, Morgan K, Kalsheker N. Amyloid precursor protein (APP) and biology of proteolytic processing: relevance to Alzheimer's disease. International Journal of Biochemistry and Cell Biology 2003;35: 1505-1535.

70. Schuh AF, Rieder CM, Rizzi L, Chaves M, Roriz-Cruz M. Mechanisms of brain aging regulation by insulin: implications for neurodegeneration in late-onset Alzheimer's disease. ISRN Neurol 2011:2011:306905.

71. Williamson R, McNeilly A, Sutherland C. Insulin resistence in the brain an old-age or new-age problem? Bioch Pharmacol 2012;84:737-45.

72. Farris W, Mansourian S, Chang Y, et al. Insulin-degrading enzyme regulates the levels of insulin, amyloid beta-protein, and the beta-amyloid precursor protein intracellular domain in vivo. Proc Natl Acad Sci U S A 2003;100:4162-4167.

73. Whitmer RA. Type 2 diabetes and risk of cognitive impairment and dementia. Curr Neurol Neurosci Rep 2007;7:373-380.

74. Watson GS, Peskind ER, Asthana S, et al. Insulin increases CSF Abeta42 levels in normal older adults. Neurology 2003;60:1899-903.

75. Gasparini L, Netzer WJ, Greengard P, Xu H. Does insulin dysfunction play a role in Alzheimer's disease. Trends Pharmacol Sci 2002;23:288-93.

76. Messier C, Teutenberg K. The role of insulin, insulin growth factor, and insulin-degrading enzyme in brain aging and Alzheimer's disease. Neural Plast 2005:12:311-328.

77. Xie L, Helmerhorst E, Taddei K, Plewright B, Van Bronswijk W, Martins R. Alzheimer's beta-amyloid peptides compete for insulin binding to the insulin receptor. J Neurosci 2002;22:RC221.

78. Phiel CJ, Wilson CA, Lee VM, Klein PS. GSK-3alpha regulates production of Alzheimer's disease amyloid-beta peptides. Nature 2003;423: 435-439.

79. Takashima A. Amyloid-beta, tau, and dementia. J Alzheimers Dis 2009;17:729-736.

80. Schubert M, Brazil DP, Burks DJ, et al. Insulin receptor substrate-2 deficiency impairs brain growth and promotes tau phosphorylation. J Neurosci 2003;23:7084-7092

81. Schubert M, Gautam D, Surjo D, et al. Role for neuronal insulin resistance in neurodegenerative diseases. Proc Natl Acad Sci U S A 2004 101:3100-3105

82. de la Monte SM, Chen GJ, Rivera E, Wands JR. Neuronal thread protein regulation and interaction with microtubule-associated proteins in SH-Sy5y neuronal cells. Cell Mol Life Sci 2003;60:2679-2691.

83. Doble BW. Woodgett JR. GSK-3: tricks of the trade for a multitasking kinase. J Cell Sci 2003;116:1175-1186.

84. Fraser $P E, Y u G$, Levesque L, et al. Presenilin function: connections to Alzheimer's disease and signal transduction. Biochem Soc Symp 2001;67:89-100 
85. Grilli M, Ferrari Toninelli G, Uberti D, et al. Alzheimer's disease linking neurodegeneration with neurodevelopment. Funct Neurol 2003;18: 145-148. 32.

86. Bhat R, Xue Y, Berg S, et al. Structural insights and biological effects of glycogen synthase kinase 3-specific inhibitor AR-A014418. J Biol Chem 2003;278:45937-45945.

87. Lebouvier T, Scales TM, Williamson R, et al. The microtubule-associated protein tau is also phosphorylated on tyrosine. J Alzheimers Dis 2009;18:1-9.

88. Morales I, Farias G, Maccioni RB. Neuroimmunomodulation in the pathogenesis of Alzheimer's disease. Neuroimmunomodulation 2010; 17: 202-204.
89. Hanger DP, Seereeram A, Noble W. Mediators of tau phosphorylation in the pathogenesis of Alzheimer's disease. Expert Rev Neurother 2009;9:1647-1666.

90. Iqbal K, Liu F, Gong CX, Alonso Adel C, Grundke-lqbal I. Mechanisms of tau-induced neurodegeneration. Acta Neuropathol 2009;118: 53-69.

91. Ling X, Martins RN, Racchi M, et al. Amyloid beta antogonizes insulin promoted secretion of the amyloid beta protein precursor. J Alzheimers Dis 2002;4:369-374.

92. Zheng WH, Kar S, Quiron R. Insulin-like growth fator-1 (IGF-1): a neuroprotective trophic fator acting via the AKT Kinase pathway. J Neurol Transm Suppl 2000;60:61-272. 